\title{
Lactobacillus plantarum strains isolated from naturally fermented sausages and their technological properties for application as starter cultures
}

\author{
Lactobacillus plantarum isolados de salames artesanais naturalmente \\ fermentados e suas propriedades tecnológicas como culturas iniciadoras \\ Maristela Cortez SAWITZKI ${ }^{1 *}$, Ângela Maria FIORENTINI ${ }^{1,2}$, \\ Teresinha Marisa BERTOL ${ }^{3}$, Ernani Sebastião SANT'ANNA ${ }^{1}$
}

\section{Resumo}

No presente estudo foram investigadas as propriedades tecnológicas de culturas de L. plantarum, isoladas de salames artesanais, naturalmente fermentados, manufaturados na região Sul do Brasil, a fim de obter um cultivo iniciador. As propriedades tecnológicas investigadas foram as seguintes: habilidade das culturas para crescer em diferentes valores de $\mathrm{pH}$, em diferentes concentrações de sal e na presença de sal de cura comercial; rápida produção de ácido, produção do isômero D - ou L - ácido láctico, atividade nitrato redutase, atividade antagonística e estabilidade das culturas após processo de fermentação, concentração e liofilização. Todas as culturas apresentaram eficiência quanto às propriedades tecnológicas investigadas.

Palavras-chave: L. plantarum; propriedades tecnológicas; salame.

\begin{abstract}
In the present study, technological properties of L. plantarum strains isolated from naturally fermented sausages manufactured in the South region of Brazil were investigated in order to obtain a starter culture. The technological properties evaluated were the following: ability to growth at different $\mathrm{pH}$ values, at different temperatures, in different salt concentrations and in the presence of commercial curing salt, fast production of acid, determination of $\mathrm{D}$ - and $\mathrm{L}$ - lactic acid; nitrate reductase activity; antagonistic activity and stability of the isolated cultures after fermentation, concentration, and freeze-drying process. The isolated strains showed effectiveness to improve technological properties as starter cultures.
\end{abstract}

Keywords: L. plantarum; technological properties; sausage.

\section{Introduction}

The manufacture of fermented foods has a long tradition. At first, there was a purely empirical principle without the connection between metabolic activity of microorganisms (so-called "house flora") and desired changes in the product (GEISEN; LÜCKE; KRÖCKEL, 1992). The fermentation process was used to improve shelf-life and safety of foods enabling people in moderate and cold regions to survive winter seasons and drought periods (HOLZAPFEL, 1997). Spontaneous fermentation of sausages is characterized by the participation of lactic acid bacteria, Gram-positive, catalase-positive cocci, yeasts, and moulds (BUCKENHÜSKES, 1993).

Modern starter cultures are selected either as single or multiple strains specifically due to their adaptation to the substrate or raw material (HOLZAPFEL, 2002). The Iinoculation of sausage batter with a starter culture composed of selected lactic acid bacteria, i. e. homofermentative lactobacilli and/ or pediococci and Gram-positive, and catalase-positive cocci (staphylococci and/or kokuriae) improves quality, safety, properties standardization, including flavor and color, and shortening in the ripening time (LEROY; VERLUYTEN; VUYST, 2006; RANTSIOU et al., 2005). Lactic acid bacteria have the main role in this microbial consortium since they affect both the technological properties and the microbial stability of the final product through the production of lactic and acetic acids and the consequent $\mathrm{pH}$ decrease (DROSINOS et al., 2007).

Meat fermentation by natural lactic acid bacteria can sometimes fail leading to products of poor quality. For this reason, the addition of starter cultures has been recommended and has become common in the manufacture of several types of fermented sausages (ANDRIGUETTO; ZAMPESE; LOMBARDI, 2001; HOLZAPFEL, 2002). In artisanal production of traditional fermented sausages, it is important to use starter cultures consisting of lactobacilli isolated from local products and that are well adapted to the particular product and to the specific production technology (ANDRIGUETTO; ZAMPESE; LOMBARDI, 2001). Starter cultures contain lactic acid bacteria

Recebido para publicação em 22/9/2007

Aceito para publicação em 7/4/2008 (002873)

Departamento de Ciência e Tecnologia de Alimentos, Centro de Ciências Agrárias, Universidade Federal de Santa Catarina - UFSC, Rodovia Admar Gonzaga, 1346,

CEP 88034-001, Florianópolis - SC, Brasil, E-mail: sawitzki@brturbo.com.br

2 Departamento de Biologia e Química, UNIJUÍ, RS 344, km 39, CEP 98900-000, Santa Rosa - RS, Brazil

${ }^{3}$ EMBRAPA SUÍNOS e AVES, BR 153, km 110, Vila Tamanduá, CEP 89700-000, Concórdia - SC, Brazil

${ }^{*}$ A quem a correspondência deve ser enviada 
originated from meat and are considered well adapted to the ecology of meat fermentation (HUGAS et al., 1993). The fitness of commercial meat starter cultures when applied to a particular type of salami is questionable since a culture that performs well in one type of fermented sausage is not necessarily efficient in another type (LEROY; VERLUYTEN; VUYST, 2006).

The aim of the present work was to investigate technological properties of Lactobacillus plantarum strains isolated from naturally fermented sausages manufactured in the South region of Brazil in order to obtain a starter culture for fermented meat products.

\section{Materials and methods}

\subsection{Bacterial strains and growth conditions}

Seven strains of $L$. plantarum were used in this study (AJ2, AL2, R2, AF5, AD3, N3, and AM2). These strains were selected from a previous study of morphological, phenotypic, and molecular characterization of ten strains isolated and characterized by Sawitzki et al. (2007).

All strains were grown in de Man Rogosa and Sharp agar (MRS; Merck, Darmstadt, Germany) plates and were anaerobically incubated at $37^{\circ} \mathrm{C}$ for 48 hours. They were sub-cultured twice ( $1 \%$ inoculum, $37^{\circ} \mathrm{C} / 24$ hours) in $10 \mathrm{~mL}$ MRS broth (Merck, Darmstadt, Germany) and kept frozen at $80^{\circ} \mathrm{C}$ in the presence of $20 \%$ glycerol.

To test the antagonistic activity, the following reference strains were acquired from the Collection André Tosello Foundation: Staphylococcus xylosus ATCC 29971, Listeria monocytogenes NTC 098630, Escherichia coli ATCC 25922, and Staphylococcus aureus ATCC 12598. One strain of Staphylococcus xylosus isolated from an artisanal sausage and manufactured without the addition of a starter culture was also used for the tests of antagonistic activity.

\subsection{Technological properties}

Technological properties for each natural strain of $L$. plantarum were investigated according to Buckenhüskes (1993), Holzapfel (2002), Lee, Kim, Kunz (2006), Saarela et al. (2006). In addition, the growth of the strains in the presence of commercial curing salt was also evaluated according to the manufacturer's instructions.

In order to test the antagonistic activity, strains which present poisoning risks in fermented sausage were selected (LEROY; VERLUYTEN; VUYST, 2006). S. xylosus strains were also tested once it is one of the most important microorganisms used as starter culture (GEISEN; LÜCKE; KRÖCKEL, 1992).

All tests were conducted in duplicate.

\section{Ability to grow at pH 3.9, fast production of acid, and determination of $D-/ L$ - lactic acid}

Growth at pH 3.9 was observed after 3 days of incubation at $37^{\circ} \mathrm{C}$ on MRS agar (Merck, Darmstadt, Germany) plates adjusted with $\mathrm{HCl}(1 \mathrm{M})$. The fast production of acid was monitored by measuring the $\mathrm{pH}$ decrease over a 12 hour-fermentation (MRS broth, Merck, Darmstadt, Germany). Fermentation was carried out in a fermentor (New Brunswick scientific model Bioflo 2000, New Brunswick, USA). Each culture of $L$. plantarum was first growth in $45 \mathrm{~mL}$ of MRS broth (Merck, Darmstadt, Germany) for 12 hours at $37^{\circ} \mathrm{C}$ when the inoculum was added in $4.5 \mathrm{~L}$ of the fermentation medium. The lactic acid isomer produced by each strain was determined with a D-/L- lactic acid enzymatic kit (R - Biopharm AG, Darmstadt, Germany) according to the manufacturer's instructions.

\section{Growth in high salt concentration and in the presence of commercial curing salt}

Growth in high salt concentration was observed after 3 days of incubation at $37^{\circ} \mathrm{C}$ on MRS agar (Merck, Darmstadt, Germany) plates added with 6.0 and $7.0 \%$ of $\mathrm{NaCl}$ (Merck, Darmstadt, Germany), respectively. Growth in the presence of commercial curing salt was observed after 3 days of incubation at $37^{\circ} \mathrm{C}$ on MRS agar (Merck, Darmstadt, Germany) plates added with commercial curing salt (Cura 102 - Duas Rodas Industrial Ltda, Jaraguá do Sul, Brazil), with sodium nitrate and sodium nitrite in respective concentrations of 300 and $150 \mathrm{mg} \cdot \mathrm{kg}^{-1}$.

\section{Nitrate reductase activity}

For the nitrate reductase test, a swab of each culture of L. plantarum was grown on MRS agar (Merck, Darmstadt, Germany) plates (anaerobically incubated at $37^{\circ} \mathrm{C}$ for 48 hours) and suspended in sterile peptone water $0.1 \%$ with turbidity equivalent to $0.5 \mathrm{McF}$ arland. A $1.0 \mathrm{~mL}$ aliquot of homogenized bacterial suspension was added to a sterile tube containing nitrate broth (DIFCO, Lawrence, USA). All tubes were incubated anaerobically at $37^{\circ} \mathrm{C}$ for 48 hours. After the incubation period, 1 drop of each reagent of the NIT test (NIT $1+$ NIT 2 reagents bioMérieux ${ }^{\oplus}$ sa, Marcy l'Etoile, France) was added to each tube. After 10 minutes, the presence of red color indicated positive reaction to the reduction of nitrate to nitrite. A negative control with no substrate and a positive control with a culture of S. xylosus positive for nitrate redutase were used.

Stability of cultures after fermentation, concentration, and freeze-drying process

Cells ( $45 \mathrm{~mL}$ of an initial inoculum $-10^{9} \mathrm{cfu} \cdot \mathrm{mL}^{-1}$ ) were grown in 4.5L of MRS broth (Merck, Darmstadt, Germany) using a fermentor (New Brunswick Scientific model Bioflo 2000, Edison, USA) under the following conditions: temperature of $37^{\circ} \mathrm{C}$, stirring at $80 \mathrm{rpm}$, and aeration of $0.7 \mathrm{vvm}$ (L filtered air atmospheric/L medium/minutes) for 12 hours. The bacterial population was determined during fermentation by plate count analysis and respective optic density at $600 \mathrm{~nm}$ of the fermentation medium. After 12 hours of fermentation (DO 2.408 and respective microbial population of Log $9 \mathrm{cfu} \cdot \mathrm{mL}^{-1}$ - logarithmic growth phase) cells were concentrated by centrifugation at $4000 \times \mathrm{g}$, 30 minutes, $4{ }^{\circ} \mathrm{C}$ (Novatécnica RC, model NT825, Piracicaba, Brazil), re-suspended to $1 / 50$ of the original broth volume in reconstituted skimmed milk ( $\left.10 \% \mathrm{w} \cdot \mathrm{v}^{-1}\right)$ as cryoprotectant, and stored at $-20{ }^{\circ} \mathrm{C}$. Freeze-drying was performed in a freezedryer (Terroni-Fauvel model LT 1000/8, São Carlos, Brazil) for 
24 hours. Freeze-dried cultures were stored at $-20^{\circ} \mathrm{C}$. Freezedried cultures were re-suspended in sterile $0.1 \%$ peptone water $\left(2.5 \times 10^{-3}\right.$ g.mL $\left.{ }^{-1}\right)$ after 4 weeks and 6 months of storage and inoculated into MRS agar using the pour plate technique (Merck, Darmstadt, Germany) (anaerobically at $37^{\circ} \mathrm{C}$ for 48 hours). The bacterial population was determined by plate count analysis in order to evaluate the stability of the cultures at $-20^{\circ} \mathrm{C}$.

\section{Antagonistic activity}

The antagonistic activity of isolated cultures of lactic acid bacteria was detected by the spot-on-lawn method according to Lewus, Kaiser, Montville (1991), Okereke, Montville (1991). TSA agar (Tryptic Soy Agar; Merck, Darmstadt, Germany) supplemented with $0.5 \%$ yeast extract (Merck, Darmstadt, Germany) was named TSAYE and used as the bottom (bacteriocin production) agar. Two microliters of each overnight MRS broth cultures of $L$. plantarum were spotted onto TSAYE plates and incubated anaerobically at $37^{\circ} \mathrm{C}$ for 48 hours. After incubation, an overlay with approximately $8 \mathrm{~mL}$ of BHI (Brain Heart Infusion; Merck, Darmstadt, Germany) containing 1\% agar and $10^{5}$ to $10^{6} \mathrm{cfu} \cdot \mathrm{mL}^{-1}$ of each test culture was added to each plate. The cultures tested were the following: S. xylosus ATCC 29971, L. monocytogenes NTC 098630, E. coli ATCC 25922, S. aureus ATCC 12598, and S. xylosus isolated from artisanal sausage. Plates with the overlay and a control plate (without any tested culture) were incubated anaerobically at $30^{\circ} \mathrm{C}$ for 48 hours and observed regarding to inhibition zones. The antagonistic activity was positive when the width of the clear zone (halo) around the colonies of the producing strain was $3.0 \mathrm{~mm}$ or larger according to Sarkar, Banerjee (1996).

\section{Results and discussion}

All L. plantarum isolated strains were able to grow at $\mathrm{pH}$ 3.9 at $37^{\circ} \mathrm{C}$ on MRS agar. During fermentation in MRS broth, they presented fast production of acid since the average $\mathrm{pH}$ values (of the respective fermentation medium) decreased from 6.48 to 4.43 after 16 hours of fermentation (Figure 1).

The most important change brought about by lactic acid bacteria in a ripened meat product is the decrease of $\mathrm{pH}$ (to below 5.0) by the secretion of lactic acid (GEISEN; LÜCKE; KRÖCKEL, 1992). The ability of strains to produce acid and growth at $\mathrm{pH} 3.9$ is significant once the acid production and consequent decrease of $\mathrm{pH}$ in sausages can cause coagulation of meat proteins, necessary reactions for color formation, and improvement of the product stability (BUCKENHÜSKES, 1993). Due to the decrease of the water-binding capacity of meat proteins, the acidification accelerates drying out and thus shortens the processing time (JESSEN, 1995).

The ability of lactic acid bacteria, in particular lactobacilli, to decrease $\mathrm{pH}$ prevents the growth of pathogenic and spoilage microorganisms improving the hygienic safety and storage of meat products (LUCKE, 1985; SAMELIS et al., 1994). A rapid $\mathrm{pH}$ drop to below 5.3 proved to be important for the inhibition of salmonella and $S$. aureus if products since such products are fermented at temperatures above $18{ }^{\circ} \mathrm{C}$ (SCHILLINGER; LÜCKE, 1989). The growth of Clostridium botulinum and
Clostridium sporogenes were susceptible to nitrite inhibition only at $\mathrm{pH}$ values below 7.0 (GRAY; PEARSON, 1984). The acidification of ground meat during the production of dry sausage, for instance, can be obtained by adding gluconadelta-lactona or by fermentation. In both cases, the shelf life safety and slice ability of the sausage will be achieved, but the original taste and flavor can only be obtained by fermentation (BUCKENHÜSKES, 1993).

Lactic acid is produced by lactic acid bacteria in two isomeric forms: L - lactic acid and D - lactic acid (SHU; HÅKANSON; MATTIASSON, 1995). The isomers L - and D -, produced during fermentation, are typically related to the Lactobacillus genus from which they are produced: for example, $\mathrm{D}(-)$ lactic acid from $L$. delbrueckii (all subspecies), L (+) from L. case, and a racemate (DL) from $L$. sakei and all heterofermentative lactobacilli (HOLZAPFEL, 2002). L. plantarum produces a racemate DL - lactate (KLANDER; WEISS, 1986). Most lactobacilli are $\mathrm{DL}$ - lactate producers, but the ratio of the two isomers is slightly variable (GOFFIN et al., 2005).

In the present work, all the L. plantarum strains isolated produced DL - lactate on the average ratio of $67.23 \%$ of $\mathrm{L}$ - lactic acid and $32.76 \%$ of D - lactic acid $\left(\right.$ w. $\left.\mathrm{v}^{-1}\right)$ as a final product of sugar fermentation. L. plantarum strain ATCC 8014 produced $1.16 \%$ of D - lactic acid and $98.84 \%$ of L - lactic acid (w. $\left.{ }^{-1}\right)$ (Table 1). Lactic acid isomers showed differences in antibacterial mechanisms, for example, L. monocytogenes (relatively acid tolerant pathogen) is more sensitive to $\mathrm{D}$ - than to $\mathrm{L}$ - lactic acid (GRAVESEN et al., 2004). In this case, the production of $\mathrm{D}$ - lactic acid by L. plantarum isolated is an important factor, but further investigation of the concentration of this isomer in fermented foods and beverages is necessary, once high levels of the D - lactic acid are not hydrolysed by D - lactic dehydrogenases in humans being capable of causing acidosis (LIU, 2003; HOLZAPFEL, 2002; ZHANG et al., 2003).

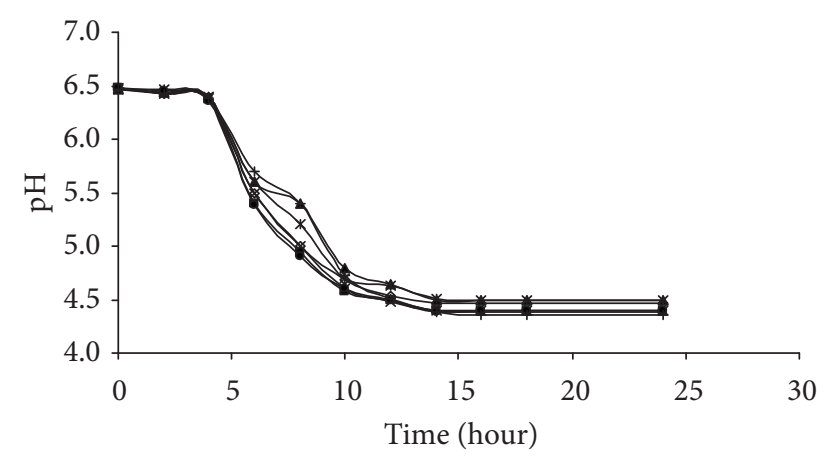

\begin{tabular}{|c|c|}
\hline $\begin{array}{l}\rightarrow \text { L. plantarum AJ2 } \\
- \text { L. plantarum AL2 } \\
\approx \text { L. plantarum R2 } \\
\star \leftarrow \text { L. plantarum AF5 }\end{array}$ & $\begin{array}{l}\text { * L. plantarum AD3 } \\
\text { - L. Llantarum AN3 } \\
+ \text { L. plantarum AM2 }\end{array}$ \\
\hline
\end{tabular}

Figure 1. $\mathrm{pH}$ values in the fermentation medium (de Man Rogosa and Sharp broth), inoculated with isolated L. plantarum strains over 24 hours of fermentation. 
Tolerance to $\mathrm{NaCl}$ is another significant feature for choosing a strain as starter culture in dried fermented products (ROVIRA et al., 1997). Strains that are able to grow at $6.5 \% \mathrm{NaCl}$ might result from a selection of resistant strains to high salt concentration during sausage processing $\mathrm{NaCl}$ - sensitive strains are present at the beginning of the process and may stop growing when $\mathrm{NaCl}$ concentration becomes too high (AMMOR et al., 2005a). According to Olesen and Meyer, Stahnke (2004), the initial $\mathrm{NaCl}$ concentration $(3.0 \%)$ in the sausage is a normal one. However, the final $\mathrm{NaCl}$ concentration after the maturation of the sausage can increase to $4.2-6.0 \%$ due to the loss of moisture in the product (MORETTI et al., 2004; PAPADIMA et al., 1999; ZANARDI et al., 2004).

Papamanoli et al. (2003) found that seven L. plantarum strains isolated from naturally fermented dry sausage were able to grow in $6.5,8.0$, and $10 \%(\mathrm{w} / \mathrm{w})$ of $\mathrm{NaCl}$. In the present study, 3 out of 7 isolated strains (L. plantarum AL2, L. plantarum AD3 and L. plantarum AM2) were able to grow on MRS agar supplemented with 6.0 and $7.0 \%$ of $\mathrm{NaCl}$.

Curing salt as well as lactic acid and $\mathrm{NaCl}$ are important elements concerning sensory, microbial and physiochemical characteristics of meat products. In this study, all isolated strains were able to grow on MRS agar plates supplemented with commercial curing salt in the respective concentration for fermented sausages $\left(300 \mathrm{mg} \cdot \mathrm{kg}^{-1}\right.$ of nitrate and $150 \mathrm{mg} \cdot \mathrm{kg}^{-1}$ of nitrite).

According to Deibel (1974); Smith, Palumbo (1983), salt and nitrite-tolerant (growth vigorously at $6 \% \mathrm{NaCl}$ and $100 \mathrm{ppm}$ nitrite) are desirable characteristics of a meat starter culture. Tolerance to cure salt is another significant factor for selecting a strain as starter culture in dried fermented meat products because the curing is an efficient conservation technique. Nitrite as curing agent is a preservative and the only agent with protective effect against toxin-forming bacteria such as C. botulinum (CAMMACK et al., 1999). According to Gray, Pearson (1984), citing Kramlich, Pearson, Tauber (1973), nitrite has several important functions in meat products: (1) stabilize color, (2) contribute to the characteristic flavor of cured meat, (3) inhibit the growth of a number of food poisoning and spoilage bacteria, especially of C. botulinum, and (4) retard the development of rancidity. The use of nitrate is interesting because it improves flavor when compared to nitrite (WIRTH, 1991). According to Gray, Pearson (1984), the American Meat Institute stated that

Table 1. Determination of lactic acid (D/L isomers) in fermentation medium (MRS broth) after 16 hours of fermentation and $\mathrm{pH}$ around 4.43.

\begin{tabular}{|c|c|c|c|c|c|c|}
\hline \multirow[t]{2}{*}{ L. plantarum } & \multicolumn{3}{|c|}{ D - lactic acid } & \multicolumn{3}{|c|}{ L - lactic acid } \\
\hline & $\%$ & g. L $^{-1}$ & mMol.L $\mathrm{L}^{-1}$ & $\%$ & g. $\mathrm{L}^{-1}$ & $\mathrm{mMol} . \mathrm{L}^{-1}$ \\
\hline ATCC 8014 & 1.16 & 0.010 & 0.11 & 98.84 & 0.841 & 9.24 \\
\hline AL2 & 34.70 & 0.209 & 2.32 & 65.28 & 0.393 & 4.32 \\
\hline $\mathrm{AJ} 2$ & 33.53 & 0.058 & 0.64 & 66.47 & 0.115 & 1.26 \\
\hline AM2 & 34.66 & 0.078 & 0.86 & 65.33 & 0.147 & 1.61 \\
\hline AD3 & 31.30 & 0.072 & 0.79 & 68.69 & 0.158 & 1.74 \\
\hline AN3 & 29.67 & 0.067 & 0.74 & 70.73 & 0.159 & 1.75 \\
\hline AF5 & 34.32 & 0.069 & 0.76 & 65.68 & 0.132 & 1.45 \\
\hline R2 & 31.13 & 0.066 & 0.73 & 68.86 & 0.146 & 1.60 \\
\hline
\end{tabular}

nitrate is changed to nitrite by the action of microorganisms and these organisms may play an important role on the typical flavor produced in meat products. For Marco, Navarro, Flores (2006), the addition of nitrate and/or nitrite in the manufacturing of dry-fermented sausage hardly affects the sensory characteristics. However, nitrite and nitrate affect both the oxidative process and the generation of volatile compounds originated from the growth and metabolism of microorganisms.

In a long curing process, nitrate is necessary as a source of nitrite by the action of nitrate reductase enzymes (TOLDRÁ, 2005 mentioned by MARCO; NAVARRO; FLORES, 2006). To enable the reddening process of the cured meat, the reduction of nitrate to nitrite is essential. Under conditions of sausage fermentation, this reaction is only possible by a nitrate reductase, which normally derives from Micrococcacea (BUCKENHÜSKES, 1993). However, some lactobacilli strains may reduce nitrate $\left(\mathrm{NO}_{3}^{-}\right)$to nitrite $\left(\mathrm{NO}_{2}^{-}\right)$and monoxide nitrogen $(\mathrm{NO})$ under anaerobic conditions (WOLF; HAMMES, 1988). Four Lactobacllus fermentum strains tested by Xu, Verstraete (2001) showed nitrate redutase activity under anaerobic conditions, but two L. plantarum strains did not show the respective activity. Some strains of L. plantarum are able to reduce nitrate under low glucose concentration and $\mathrm{pH}$ at 6.0 or higher (KLANDER; WEISS, 1986). In the present study no $L$. plantarum isolated showed nitrate reductase activity in the nitrate broth incubated anaerobically at $37^{\circ} \mathrm{C}$ for 48 hours. According to BUCKENHÜSKES (1993), the curing of meat products in the absence of cocci is only accepted when the lactic acid bacteria present have significant high nitrate reductase activities. Therefore, if the product fermentation process demands activity of nitrate reductase, the use of the L. plantarum strains isolated should be associated with a micrococaceae strain or other lactic acid bacteria strain that exhibit the respective activity.

All isolated cultures showed stability after freeze-drying process after 4 weeks and 6 months of storage at $-20^{\circ} \mathrm{C}$ because cells viability status remained at 9 Log cfu.mL $\mathrm{mL}^{-1}$ (Table 2). Further investigations are necessary to show possible changes in cell functionality.

Regarding antagonistic activity, lactic acid bacteria isolated from traditional sausage are probably the best candidates for improving the microbiological safety of these products because they are well adapted to the conditions found in sausages and therefore should be more competitive than lactic acid bacteria from other sources (AMMOR et al., 2005b). The main mechanism

Table 2. Stability of $L$. plantarum strains isolated after freeze-dried process and during storage at $-20^{\circ} \mathrm{C}$.

\begin{tabular}{lccc}
\hline & \multicolumn{3}{c}{$\begin{array}{c}\text { Microbial population at }-20^{\circ} \mathrm{C} \\
\text { (mean values Log cfu.mL }\end{array}$} \\
& \multicolumn{1}{c}{ initial } & 4 weeks & 6 months \\
\hline \multicolumn{1}{c}{ Microrganism } & $8.89 \pm 0.2$ & $9.12 \pm 0.6$ & $8.95 \pm 0.1$ \\
L. plantarum AJ2 & $9.86 \pm 0.7$ & $9.92 \pm 0.2$ & $9.89 \pm 0.2$ \\
L. plantarum AL2 & $9.20 .7 \pm 0.7$ \\
L. plantarum R2 & $9.23 \pm 0.3$ & $8.78 \pm 0.3$ & $9.20 \pm 0.6$ \\
L. plantarum AF5 & $9.58 \pm 0.1$ & $9.65 \pm 0.8$ & $9.63 \pm 0.6$ \\
L. plantarum AD3 & $9.86 \pm 0.2$ & $9.89 \pm 0.3$ & $9.81 \pm 0.1$ \\
L. plantarum AN3 & $9.76 \pm 0.2$ & $9.79 \pm 0.2$ & $9.74 \pm 0.5$ \\
L. plantarum AM2 & $9.39 \pm 0.1$ & $9.25 \pm 0.5$ & $8.97 \pm 0.3$ \\
\hline
\end{tabular}


Table 3. Antagonistic activity of $L$. plantarum strains isolated from artisanal sausage.

\begin{tabular}{lcccccccc}
\hline \multicolumn{10}{c}{ L. plantarum strains isolated } \\
\hline \multicolumn{1}{c}{ Reference strains } & AL2 & AJ2 & AD3 & R2 & AM2 & AN3 & AF5 \\
\hline S. xylosus ATCC 29971 & + & - & + & - & - & + & + \\
S. xylosus isolated & - & - & + & - & - & + & + \\
S. aureus ATCC 12598 & - & + & - & + & + & - & + \\
E. coli ATCC 25922 & - & - & - & - & - & - & - \\
L. monocytogenes & + & + & + & + & + & + & + \\
NTC 098630 & & & & & & &
\end{tabular}

Symbols for well diffusion assay: (+) large inhibition zone (width $\geq 3.0 \mathrm{~mm}$ ); (-) no inhibition zone.

by which lactic acid bacteria suppress their competitors is the formation of lactic acid (the most important mechanism of action of protective cultures), acetic acid, and, possibly, bacteriocins (LÜCKE, 2000). Other metabolites of lactic acid bacteria inhibit Gram-negative bacteria in vitro, but it is unlikely that they will be exploited to improve the safety and stability of meats. Some are not formed in sufficient amounts (e.g. reuterin), some interfere with the sensory properties (e.g. diacetyl, hydrogen peroxide), and some raise regulatory concern (e.g. benzoic acid) (LÜCKE, 2000).

Bacteriocinogenic lactic acid bacteria have shown effective inhibition of growth of pathogens, such as L. monocytogenes, S. aureus, Bacillus cereus and Clostridium dificile, even under in situ conditions (HOLZAPFEL; GEISEN; SCHILLINGER, 1995). According to Papamanoli et al. (2003), out of seven L. plantarum strains isolated from naturally fermented dry sausage, five showed antimicrobial activity against $L$. monocytogenes strains and two inhibited growth of two strains of $S$. aureus, but no inhibition was observed against strains of E. coli 0157:H7 and B. cereus.

In the present work, seven isolated strains exhibited antagonistic activity against $L$. monocytogenes NTC 098630, four isolated strains inhibited the growth of S. aureus ATCC 12598 and S. xylosus ATCC 29971, and three isolated strains inhibited the growth of S. xylosus strain isolated; no inhibition was observed against E. coli ATCC 25922 (Table 3).

The results indicate antagonistic activity of $L$. plantarum isolated strains, but further studies are necessary to define the chemical nature, classification and characterization of these antimicrobial compounds. According to Geisen, Lücke, Kröckel (1992), in order to select a microorganism as starter culture it is also important to consider no inhibition against Gram-positive and catalasepositive cocci (e.g. S. xylosus) since this microorganism ensures the sensory quality of fermented sausage.

\section{Conclusions}

Isolated strains of $L$. plantarum showed effective technological properties as starter culture, but additional studies of those properties in naturally fermented sausages are necessary.

\section{Acknowledgements}

The financial support of this work was provided by EMBRAPA, UNIJUÍ, and UFSC, Brazil.

\section{References}

AMERICAN MEAT INSTITUTE. Beef, veal and lamb operations. 4 ed. Chicago: Institute of Meat Packing; University of Chicago, 1945.

AMMOR, S. et al. Characterization and selection of Lactobacillus sakei strains isolated from traditional dry sausage for their potential use as starter cultures. Food Microbiology, v. 22, p. 529-538, 2005 a.

AMMOR, S. et al. Phenotypic and genotypic identification of lactic acid bacteria isolated from a small-scale facility producing traditional dry sausages. Food Microbiology, v. 22, p. 373-382, 2005 b.

ANDRIGUETTO, C.; ZAMPESE, L.; LOMBARDI, A. RAPD-PCR characterization of lactobacilli isolated from artisanal meats plants and traditional fermented sausages of Veneto region (Italy). Letters in Applied Microbiology, v. 33, p. 26-30, 2001.

BUCKENHÜSKES, H. J. Selection criteria for lactic acid bacteria to be used as starter cultures for various food commodities. FEMS Microbiology Reviews, v. 12, p. 253-272, 1993.

CAMMACK, R. et al. Nitrite and nitrosyl compounds in food preservation. Biochimica et Biophysica Acta, v. 1411, p. 475-488, 1999.

DEIBEL, R. H. Technology of fermented semi-dried and dried sausage. In: MEAT INDUSTRY RESEARCH CONFERENCES, March 23-24. Proceedings... Chicago: Am. Meat Institute Foundation, 1974.

DROSINOS, E. H. et al. Phenotypic and technological diversity of lactic acid bacteria and staphylococci isolated from traditionally fermented sausages in Southern Greece. Food Microbiology, v. 24, p. 260-270, 2007.

GEISEN, R.; LÜCKE, F. K.; KRÖCKEL, L. Starter and protective cultures for meat and meat products. Fleischwirtsch, v. 72, n. 6, p. 894-898, 1992.

GOFFIN, P. et al. Lactate racemization as a rescue pathway for supplying $\mathrm{D}$ - lactate to the cell wall biosynthesis machinery in Lactobacillus plantarum. Journal of Bacteriolog, v. 187, p. 6750-6761, 2005.

GRAVESEN, A. et al. Differential inactivation of Listeria monocytogenes by D - and L - lactic acid. Letters in Apllied Microbiology, v. 39, p. 528-532, 2004.

GRAY, J. I.; PEARSON, A. M. Cured meat flavor. In: Advances in food research. [S.L.]: Academic Press, 1984. V. 29, p. 1-86.

HOLZAPFEL, W. H.; GEISEN, R.; SCHILLINGER, U. Biological preservation of foods with reference to protective cultures, bacteriocins and food-grade enzymes. International Journal of food Microbiology, v. 24, p. 343-362, 1995.

HOLZAPFEL, W. Use of starter cultures in fermentation on household scale. Food Control, v. 8, n. 5-6, p. 241 - 258, 1997.

HOLZAPFEL, W. H. Appropriate starter culture technologies for smallscale fermentation in developing countries. International Journal of food Microbiology, v. 75, p. 197-212, 2002.

HUGAS, M. et al. Biochemical characterization of lactobacilli from dry fermented sausages. International Journal of food Microbiology, v. 18 , p. 107-113, 1993.

JESSEN, B. Starter cultures for meat fermentation. In: Fermented meats. London: Blackie Academie Professional, 1995. p. 130-159.

KLANDER, O.; WEISS, N. Genus Lactobacillus. In: Bergey's Manual of Systematic Bacteriology. New York: Springer, 1986. v. 2.

KRAMLICH, W. E.; PEARSON, A. M.; TAUBER, F. W. Processed Meats. Westport, Connecticut: AVI Publ. Co., 1973.

LEE, J. Y.; KIM, C. J.; KUNZ, B. Identification of lactic acid bacteria isolated from kimch and studies on their suitability for application as starter culture in the production of fermented sausages. Meat Science, v. 72, p. 437-445, 2006. 
LEROY, F.; VERLUYTEN, J.; VUYST, L. D. Functional meat starter cultures for improved sausage fermentation. International Journal of Food Microbiology, v. 106, p. 270-285, 2006.

LEWUS, C. B.; KAISER, A.; MONTVILLE, T. J. Inhibition of foodborne bacterial pathogens by bacteriocins from lactic acid bacteria isolated from meat. Applied and Environmental Microbiology, v. 57, n. 6, p. 1983-1688, 1991.

LIU, S. Q. Practical implications of lactate and pyruvate metabolism by lactic acid bacteria in food and beverage fermentations. International Journal of Food Microbiology, v. 83, p. 115-131, 2003

LÜCKE, F. K. Mikrobiologische Vorgänge bei der Herstellung von Rohwurst und Rohschinken. Band 5 der Kulmbacher Reihe, S, 1985. p. 85-102.

LÜCKE, F. K. Utilization of microbes to process and preserve meat. Meat Science, v. 56, p. 105-115, 2000.

MARCO, A.; NAVARRO, J. L.; FLORES, M. The influence of nitrite and nitrate on microbial, chemical and sensory parameters of slow dry fermented sausage. Meat Science, v. 73, p. 660-673, 2006.

MORETTI, V. M. et al. Chemical and microbiological parameters and sensory attributes of a typical Sicilian salami ripened in different conditions. Meat science, v. 66, p. 845-854, 2004.

OLESEN, P. T.; MEYER, A. S.; STAHNKE, L. Generation of flavour compounds in fermented sausages - the influence of curing ingredients, Staphylococcus starter culture and ripening time. Meat Science, v. 66, p. 675-687, 2004.

OKEREKE, A.; MONTVILLE, T.J. Bacteriocin inhibition of Clostridium botulinum spores by lactic acid bacteria. Journal of Food Protection, v. 54, n. 5, p. 349-353, 1991.

PAPADIMA, S. N. et al. Chemometric model for describing Greek traditional sausages. Meat science, v. 51, p. 271-277, 1999.

PAPAMANOLI, E. et al. Characterization of lactic acid bacteria isolated from a Greek dry-fermented sausage in respect of their technological and probiotic properties. Meat Science, v. 65, p. 859-867, 2003.

RANTSIOU, K. et al. Molecular characterization of Lactobacillus species isolated from naturally fermented sausages produced in Greece, Hungary and Italy. Food Microbiology, v. 22, p. 19-28, 2005.

ROVIRA, A. et al. Characterization and selection of lactobacilli isolated from Spanish fermented sausages. Microbiologia SEM, v. 13, p. 201-208, 1997.
SAARELA, M. et al. Stability and functionality of freeze-dried probiotic Bifidobacterium cells during storage in juice and milk. International Dairy Journal, v. 16, p. 1477-1482, 2006.

SAMELIS, J. et al. Quantification and characterization of microbial populations associated with naturally fermented Greek dry salami. Food Microbiology, v. 11, p. 447-460, 1994.

SARKAR, P. K.; BANERJEE, S. Antibacterial activity of lactic acid bacterial isolates obtained from natural habitats. Journal Food Science Technology, v. 33, n. 3, p. 231-233, 1996.

SAWITZKI, M. C. et al. Phenotypic characterization and species-specific PCR of promising starter culture strains of Lactobacillus plantarum isolated from naturally fermented sausages. Brazilian Journal of Microbiology, v. 38, p. 547-552, 2007.

SCHILLINGER, U.; LÜCKE, F. K. Einsatz von milchsäurebacterien als schutzkulturen bei fleischerzeugnissen. Fleischwirtschaft, v. 69, p. 879-882, 1989.

SHU, H. C.; HÅKANSON, H.; MATTIASSON, B. On-line monitoring of D - lactic acid during a fermentation process using immobilized $\mathrm{D}$ - lactate dehydrogenase in a sequential injection analysis system. Analytica Chimica Acta, v. 300, p. 277-285, 1995.

SMITH, J. L.; PALUMBO, S. A. Use of Starter Cultures in Meats. Journal of Food Protection, v. 46, n. 11, p. 997-1006, 1983.

TOLDRÁ, F. Implicaciones de la reducción de nitratos y nitritos en el jamón curado. In: CONGRESSO MUNDIAL DEL JAMÓN, 3, 2005. Session... Espanã, 2005.

XU, J.; VERSTRAETE, W. Evaluation of nitric oxide production by lactobacilli. Applied Microbiology Biotechnology, v. 56, p. 504-507, 2001.

WIRTH, F. Restricting and dispensing with curing agents in meat products. Fleischwirtschaft, v. 71, p. 1051-1054, 1991.

WOLF, G.; HAMMES, W. P. Effect of hematin on the activities of nitrite reductase and catalase in lactobacilli. Archives of Microbiology, v. 149 , p. 220-224, 1988.

ZANARDI, E. et al. Lipolysis and lipid oxidation in fermented sausages depending on different processing conditions and different antioxidants. Meat Science, v. 66, p. 415-423, 2004.

ZHANG, D. L. et al. D-lactic acidosis secondary to short bowel syndrome. Postgrade Med, v. 79, p. 110-112, 2003. 